\title{
Forest Type Influences Transmission of Phytophthora ramorum in California Oak Woodlands
}

\author{
Jennifer M. Davidson, Heather A. Patterson, Allison C. Wickland, Elizabeth J. Fichtner, and David M. Rizzo
}

First author: Pacific Southwest Research Station, United States Department of Agriculture Forest Service, P.O. Box 245, Berkeley, CA 94701; and second, third, fourth, and fifth authors: Department of Plant Pathology, One Shields Ave., University of California, Davis 95616. Current address of J. M. Davidson: Department of Zoology, 2538 McCarthy Mall, Edmondson 152, University of Hawaii, Honolulu 96822. Accepted for publication 20 October 2010.

\begin{abstract}
Davidson, J. M., Patterson, H. A., Wickland, A. C., Fichtner, E. J., and Rizzo, D. M. 2011. Forest type influences transmission of Phytophthora ramorum in California oak woodlands. Phytopathology 101:492-501.

The transmission ecology of Phytophthora ramorum from bay laurel (Umbellularia californica) leaves was compared between mixed-evergreen and redwood forest types throughout winter and summer disease cycles in central, coastal California. In a preliminary multisite study, we found that abscission rates of infected leaves were higher at mixedevergreen sites. In addition, final infection counts were slightly higher at mixed-evergreen sites or not significantly different than at redwood sites, in part due to competition from other foliar pathogens at redwood sites. In a subsequent, detailed study of paired sites where $P$. ramorum was the main foliar pathogen, summer survival of $P$. ramorum in bay laurel leaves was lower in mixed-evergreen forest due to lower recovery from infected attached leaves and higher abscission rates of infected leaves. Onset of
\end{abstract}

ABSTRACT inoculum production and new infections of bay laurel leaves occurred later in mixed-evergreen forest. Mean inoculum levels in rainwater and final infection counts on leaves were higher in redwood forest. Based on these two studies, lower summer survival of reservoir inoculum in bay laurel leaves in mixed-evergreen forest may result in delayed onset of both inoculum production and new infections, leading to slower disease progress in the early rainy season compared with redwood forest. Although final infection counts also will depend on other foliar pathogens and disease history, in sites where P. ramorum is the main foliar pathogen, these transmission patterns suggest higher rates of disease spread in redwood forests during rainy seasons of short or average length.

Additional keywords: geographic mosaic, host $\times$ pathogen interaction, Lithocarpus densiflorus, microclimate, Quercus agrifolia, sudden oak death.
Sudden oak death is an emerging disease affecting $>100$ host plants in woodlands and nurseries of the United States and Europe $(1,45)$. First reported in the San Francisco Bay Area in the mid-1990s (48), the current geographic range of the pathogen in North American natural ecosystems spans $>850 \mathrm{~km}$ from south of Big Sur, CA to Curry County in southwestern Oregon (58). Within this region, the causal agent, Phytophthora ramorum, has potentially killed millions of oak and tanoak trees and continues to invade new forest sites $(38,47)$.

At the epicenter of disease in central, coastal California, topography creates a geographic mosaic of forest types $(3,4,18,52,59)$. Although initial research has identified the main pathways of transmission for the pathogen in mixed-evergreen forests of this region (17), studies have yet to identify how the mechanisms underlying transmission can be expected to vary in different forest types throughout the current range of $P$. ramorum. Yet the ability to predict the spread of the pathogen and the severity of the disease on keystone oak (Quercus spp.) and tanoak (Lithocarpus densiflorus, recently attributed to a new genus Notholithocarpus densiflorus) (32) hosts depends on this knowledge.

Because forest types vary across a topographical landscape, there will be associated changes in microclimate and, consequently, a likelihood of variation in the host $\times$ pathogen interaction and pathogen transmission $(5,8,14,15,57)$. These changes in

Corresponding author: J. M. Davidson; E-mail address: jmd@ hawaii.edu

doi:10.1094/PHYTO-03-10-0064

This article is in the public domain and not copyrightable. It may be freely reprinted with customary crediting of the source. The American Phytopathological Society, 2011 microclimate may be due to variation in edaphic factors such as aspect, soil strata, and hydrology that underlie the growth of a particular vegetation type. Differences in the ensuing physical structure of the vegetation itself also will affect light availability and, consequently, temperature and moisture $(4,12)$. These are crucial factors that determine survival and sporulation of most pathogens, including Phytophthora spp. $(19,22)$. On the level of fine-scale host $\times$ pathogen interactions, these environmental variables may affect timing and production of inoculum, length of infectious period, degree of host susceptibility or pathogen virulence, pathogen survival through adverse conditions (dormancy), timing and incidence of new infections, and the overall magnitude and pattern of disease epidemics $(5,8,11,16,17,23,26$, $29,33,34,39,40,44,47)$.

A number of plant-pathogen studies have investigated how these underlying mechanisms of transmission change across different microenvironments. However, many of these studies have been conducted in agricultural or plantation systems $(7,23$, 29,33). Studies in natural ecosystems have mostly focused on microsite differences within one vegetation type, often at smaller spatial scales, or used artificially altered habitats $(2,33,35,36$, $43,50,53)$. Few studies in natural ecosystems have investigated the fine-scale interactions underlying pathogen transmission and how they change across vegetation types $(5,8,15,40)$.

In this study, we use the sudden oak death pathosystem to test for the effect of forest type on the transmission biology of $P$. ramorum by examining survival within, sporulation from, and infection on leaves of the same host species, California bay laurel (Umbellularia californica), in two different forest types: mixedevergreen forest (dominated by Quercus agrifolia) and redwood forest. These two forest types are common to the region of $P$. 
ramorum infestation on the west coast of the United States $(3,4,42)$.

Although $P$. ramorum infects $>25$ host species in these woodlands, nonlethal foliar lesions on bay laurel are the most important host tissue for sporulation by $P$. ramorum in oak woodlands of California $(17,21,47)$. Lesions form mainly on leaf tips or other areas where water accumulates on leaves, and have been shown to produce up to 17,000 spores/lesion under natural conditions (16). Levels of inoculum in through-fall rain are up to 20 times higher under bay laurel as opposed to other forest trees (16). In addition, at the landscape level, infection on bay laurel is known to precede infection on oak and tanoak trees, and the presence of this host is associated with higher levels of oak mortality $(28,31,54,55)$. Consequently, infections on bay laurel leaves drive the spread of $P$. ramorum and the onset of lethal infections on oak and tanoak. Understanding how the transmission biology of $P$. ramorum from bay laurel leaves varies among forest types is fundamental to predicting how $P$. ramorum will spread through the varied landscapes of central and northern California, and for determining which host species will face the greatest inoculum pressure.

We compared the transmission biology of $P$. ramorum on bay laurel leaves in mixed-evergreen versus redwood forest through multiple stages of the pathogen's disease cycle that follows annual seasonal climate patterns. This region experiences a Mediterranean climate with cool, wet winters and hot, dry summers. $P$. ramorum, like most Phytophthora spp., has a disease cycle that involves infection of host tissue, production of infective spores (sporangia containing motile zoospores), movement of infective spores, and reinfection of host tissue $(17,19,61)$. These stages require moisture and occur during the winter rainy season in the study region. In addition, resting spores (chlamydospores) are produced that may allow for survival through summer in a dormant or relatively inactive state $(17,61)$.

A multisite census of bay laurel leaves was undertaken across a series of mixed-evergreen and redwood sites in central, coastal California during 2001-2003 to assess leaf infection and abscission. The results of this census suggested that there were differences in the transmission ecology of $P$. ramorum from bay laurel leaves based on forest type. Detailed experiments were then conducted at paired sites in the Mayacama Mountains (Sonoma County, CA) during 2003-2005 to further characterize transmission in the two forest types. Through these two studies, we asked how summer survival in bay laurel leaves differed between mixed-evergreen and redwood forest by examining pathogen survival (recovery) from attached and abscised leaves, abscission of infected leaves, and leaf water potential. During the winter rainy season, we compared timing and levels of each of the following variables in the two forest types: inoculum in rainwater, inoculum from individual leaf infections, and new infections. Large differences in the length of the rainy season during the two seasons of the paired-site study (2003-04 and 2004-05) allowed us to examine the consequences of the timing of inoculum production and infection for the two forest types and their respective keystone hosts during years with short and extended spring rainfall.

\section{MATERIALS AND METHODS}

Multisite census. Research sites. The mixed-evergreen and redwood sites used in this study spanned a north-south transect of $200 \mathrm{~km}$ along the inland coast of central California. This area has a Mediterranean climate with cool, wet winters and hot, dry summers, although summer fog, crucial to redwood growth, can condense on foliage and form precipitation (42). The mixed-evergreen sites in our study were dominated by coast live oak $(Q$. agrifolia) and bay laurel, while redwood sites were dominated by tanoak, redwood (Sequoia sempervirens), and bay laurel. Redwood forests generally have lower light and temperature and higher moisture levels than mixed-evergreen forests due to greater moisture requirements for redwood and tanoak as opposed to coast live oak, as well as greater canopy height and closure (42). At the time of this study, incidence of $P$. ramorum infection on coast live oak in mixed-evergreen forests throughout this region was 4 to $30 \%$, leading to mortality rates that were four times higher than historical levels (54; J. Davidson, unpublished data). Likewise, tanoak is one of the most susceptible species to $P$. ramorum, with mortality rates reaching $>60 \%$ at some sites (31).

Infection and abscission of bay laurel leaves. During the rainy seasons of 2001-02 and 2002-03, we monitored bay laurel leaves for infection by $P$. ramorum, infection by other pathogens, and leaf abscission at five mixed-evergreen and six tanoak redwood forest sites. Although new infections are a direct reflection of transmission, abscission also can affect transmission by ridding the plant of infected leaf tissue. In addition, abscission rates can differ with moisture and light availability and, therefore, forest type $(46,63)$. The five mixed-evergreen sites were China Camp (Marin County), Fairfield Osborn Preserve (Sonoma County), Marin Municipal Water District (Marin County), Pacheco Hills in the Marin Open Space District (Marin County), and Skyline Park (Napa County). The six redwood sites were Armstrong Redwoods State Park (Sonoma County), Henry Cowell State Park (Santa Cruz County), Jack London State Park (Sonoma County), Marin Municipal Water District, Mendocino Boonville (private land in Mendocino County), and Muir Woods National Monument (Marin County).

At the beginning of the rainy season at each of the sites except for the Marin Municipal Water District, 10 uninfected terminal leaves were marked on each of 10 branches on 10 trees for a total of 1,000 leaves per site. At Marin Municipal Water District, five trees (500 leaves) were present in mixed-evergreen forest and five trees (500 leaves) were located in redwood forest. Across all sites, 4,500 leaves were located in mixed-evergreen forest and 5,500 leaves were in redwood forest for a total of 10,000 leaves. During the two rainy seasons, leaves were counted toward the end of the rainy season in March 2002 and April 2003, during midsummer in July, and at the end of the summer in October. In each census, leaves were scored for $P$. ramorum infection and abscission. Damage due to other pathogens was also noted.

If leaves had pathogen damage consistent with disease symptoms caused by $P$. ramorum infection, $\approx 4 \mathrm{~mm}^{2}$ of leaf material was excised from the margin of healthy and necrotic tissue using surface-sterilized dissecting scissors and forceps and taken back to the laboratory for pathogen isolation on a Phytophthoraselective medium (pimaricin-ampicillin-rifampicin-PCNB agar [PARP]) (19). After 2 to 3 weeks of culturing, plates were scored for $P$. ramorum and other Phytophthora spp. based on colony morphology. Other Phytophthora spp. were further identified by sequencing the internal transcribed spacer (ITS) region of ribosomal DNA (25). Data were pooled across sites within each forest type; leaves infected by other pathogens were excluded from analysis; and the association between abscission, infection by $P$. ramorum, and forest type was examined with a log-linear model (56). Specifically, we compared abscission rates of leaves infected by $P$. ramorum with those of uninfected leaves, abscission rates in mixed-evergreen versus redwood forest, and final infection counts by $P$. ramorum in the two forest types. We then used likelihood ratio $\chi^{2}$ analyses with a standard Bonferoni correction to compare abscission rates of both $P$. ramorum-infected and uninfected leaves in mixed-evergreen versus redwood forest. A separate analysis was used for each year.

To determine whether removal of leaf material affected leaf abscission in the previous experiment and others in this study, we conducted a separate experiment testing the effect of leaf removal on abscission of infected and uninfected bay laurel leaves. On 1 May 2003, at Fairfield Osborn Preserve (FOP), a mixed-evergreen site used in the paired-site study (see Methods), we selected five 
branches on each of 20 trees for experimental use. On each branch, two infected and two uninfected terminal leaves were chosen. A sterile quarter-inch hole punch was used to remove leaf material from the edge of one infected and one uninfected leaf per branch, resulting in a total of 100 leaves in each of the following categories: (i) infected, nonwounded; (ii) infected, wounded; (iii) uninfected, nonwounded; and (iv) uninfected, wounded. Leaves were counted in July and October 2003 for abscission. The effect of infection and tissue removal on leaf abscission was analyzed with a nominal logistic model. With the exception of log-linear models, all other statistical analyses in this study were performed with JMP 7 (51).

Paired-site study. Research sites. Based on the results of the multisite survey, detailed experiments during 2003-05 were conducted at 2 of the 10 sites: a mixed-evergreen forest at FOP, Sonoma County, CA $\left(122^{\circ} 35^{\prime} 41^{\prime \prime} \mathrm{W}, 38^{\circ} 20^{\prime} 37^{\prime \prime} \mathrm{N}\right)$ and a redwood forest at Jack London State Park (JLSP), Sonoma County, CA $\left(122^{\circ} \mathrm{W}, 38^{\circ} \mathrm{N}\right)$ to further investigate differences in transmission throughout the disease cycle in the two forest types. Common weather and disease history made these sites ideal for comparison of differences in transmission factors based on forest type. The two paired forest sites were separated by $5 \mathrm{~km}$ of aerial distance on opposite sides of Sonoma Mountain (elevation $700 \mathrm{~m}$ ). They experienced the same weather patterns, although their aspect, topography, and forest structure resulted in vegetation and microclimate differences, including greater precipitation at the redwood forest (J. Clothier, unpublished data; JLSP, unpublished data). Both sites had comparably high levels of infection on bay laurel trees and were likely to have a shared invasion history because $P$. ramorum was well established in the Sonoma Mountain region $(31,37)$. In addition, $P$. ramorum was the main foliar pathogen on bay laurel at both sites (see Results), meaning that competition with other foliar Phytophthora spp. (62) would not confound the transmission biology of our focal pathogen.

The research site at FOP encompassed $\approx 25$ ha of mixedevergreen forest dominated by coast live oak and bay laurel at $\approx 530 \mathrm{~m}$ of elevation. A 1-ha plot survey within the site revealed that coast live oak and bay laurel comprised 39.7 and $46.2 \%$ of the individuals, respectively. Infection levels within the plot were high: $16.5 \%$ for coast live oak and $81.9 \%$ for bay laurel (J. Davidson, unpublished data). Yearly rainfall during 2003-04 was $1,037 \mathrm{~mm}$ and during 2004-05 was $1,218 \mathrm{~mm}$ (measured July to June) (J. Clothier, unpublished data). Temperature was -1.3 to $35.4^{\circ} \mathrm{C}$ during $2003-2005$ (J. Clothier, unpublished data; J. Davidson, unpublished data). Soils in this area were volcanic in origin and in the Goulding, Toomes, Spreckles, and Raynor series (9). Soil $\mathrm{pH}$ at the site was 5.0 to 5.6 (J. Davidson, unpublished data).

The research site at JLSP consisted of $\approx 65$ ha of redwood forest dominated by tanoak, redwood, and bay laurel at 235 to $280 \mathrm{~m}$ of elevation. Relative densities of individuals were 40.0, 23.7, and $26.0 \%$ for tanoak, redwood, and bay laurel, respectively (31). Infection levels were high: Based on a 2002 study of $30500-\mathrm{m}^{2}$ plots, mean percent infection levels with $95 \%$ confidence intervals for tanoak, redwood, and bay laurel at the study site were $44.6 \pm 11.2,1.3 \pm 2.5$, and $47.8 \pm 11.1 \%$, respectively (31; R. Cobb, unpublished data). Yearly rainfall during 2003-04 was $1,200 \mathrm{~mm}$ and during 2004-05 was $1,525 \mathrm{~mm}$ (measured July to June) (JLSP, unpublished data). Temperature during the study period was -0.2 to $35.16^{\circ} \mathrm{C}$ (JLSP, unpublished data; P. Maloney, unpublished data). Soils in this forest were volcanic in origin and the dominant series were Spreckles and Goulding (9). Soil $\mathrm{pH}$ was 5.5 to $6.1(20)$.

A key difference between the 2 years of the paired-site study at both FOP and JLSP was that rainfall extended into May and June in 2005 whereas minimal amounts of rainfall were detected after February in spring 2004. Total rainfall from March to June at FOP for spring 2004 and spring 2005 was 71 and $439 \mathrm{~mm}$, respectively. The long-term average (1999 to 2005) for March to June rainfall at this study site was $220 \mathrm{~mm}$ (J. Clothier, unpublished data). Total rainfall at JLSP from March to June for spring 2004 and spring 2005 was 99 and $536 \mathrm{~mm}$, respectively. The long-term average (1973 to 2000) for March to June rainfall at JLSP was $346 \mathrm{~mm}$ (JLSP, unpublished data).

Summer survival. Pathogen recovery from attached and abscised leaves. We assessed summer survival of $P$. ramorum in (i) infected, attached and (ii) infected, abscised bay laurel leaves at the mixed-evergreen site, FOP, versus the redwood site, JLSP, throughout the summer dry season of 2003 (June to November) by plating symptomatic leaves and scoring for pathogen growth (recovery) on a monthly basis. Beginning in mid-June after winter rains stopped and hot, dry summer conditions ensued, five infected leaves were collected from both attached leaves on the tree and abscised leaves in the leaf litter of 15 trees at both sites, for a total of 75 leaves per treatment level and 300 leaves in total. Lesions from leaves were plated on PARP. Initial recovery of $P$. ramorum was scored after 3 weeks. Plates with no recovery were then stored in the dark at $15^{\circ} \mathrm{C}$. Antibiotic activity of PARP medium degrades with time; therefore, leaf lesion tissue was transferred to new PARP plates after 3 months. A final assessment was made on these plates at 4 months to allow time for $P$. ramorum to break dormancy. A nominal logistic analysis was performed on the data pooled by month to test for the effect of forest type, abscission, and their interaction on pathogen recovery. The significance of individual treatment levels on recovery then was investigated with likelihood ratio $\chi^{2}$ tests, and the effect of multiple tests accounted for using a standard Bonferoni correction.

Abscission rates of infected leaves. To compare abscission rates of infected leaves in the two forest types, we marked noninfected bay laurel leaves and monitored infection by $P$. ramorum and leaf abscission at the two forest sites throughout the rainy season and dry season in 2003-04 and 2004-05, years with shortened and extended spring rainfall, respectively. At the beginning of each rainy season before $P$. ramorum spores were detected in rainwater, 10 uninfected bay laurel leaves on each of 10 terminal branches on each of 10 trees were marked for observation, for a total of 1,000 leaves at each site. We then counted the leaves every 2 weeks during November 2003 to September 2004 and November 2004 to October 2005 to record whether leaves were infected or abscised. For symptomatic lesions, a small piece of leaf $\left(\approx 4 \mathrm{~mm}^{2}\right)$ was excised for plating on PARP to confirm the presence of $P$. ramorum. Abscission rates of infected and uninfected leaves were compared between the two forest types in a log-linear model that examined the association between abscission, $P$. ramorum infection, and forest type. We then used likelihood ratio $\chi^{2}$ analyses with a standard Bonferoni correction to evaluate abscission rates of $P$. ramorum-infected and uninfected leaves in the two forest types. A separate analysis was used for each year. This study and analysis were also used to compare the effect of forest type on infection rates in the winter rainy season (see Methods below).

Leaf water potential. Moisture levels are an important factor controlling pathogen survival. Therefore, we compared summer water potential levels in bay laurel foliage at the mixed-evergreen versus the redwood site to determine the relative difference in pathogen energy exertion required to obtain water from the host during the summer survival period. Leaf water potential was assessed at the highest point of water stress at the end of the summer in 2004 and 2006 by measuring the water potential of two replicate leaves from each of 15 trees at both sites using a pressure bomb (PMS Instrument Co., Corvallis, OR; pressure gauge manufactured by ReoTemp Instrument Corporation, San Diego, CA). For both years, a $t$ test was used to test for differences in mean water potential between the two forest sites using the average of the two leaf measurements per tree. 
Winter inoculum production and infection. Inoculum in rainwater. Overall patterns of inoculum production in the two forest types were compared by tracking timing and quantity of inoculum production in rainwater at the two sites during the rainy seasons of 2003-04 and 2004-05. Rainwater was collected from 15 locations throughout both forest sites by pooling rainwater collected from three two-gallon buckets set out at each location. Rainwater was collected approximately every 3 weeks within 1 day of the end of individual storm events (duration of 1 to 8 days). Final volume per sample was 0.5 to 3.8 liters, depending on the quantity of rainwater available from a given rain event.

To determine the concentration of $P$. ramorum propagules, rainwater was filtered through a millipore glass fiber prefilter (Fisher APFD09050) with a 2.7- $\mu$ m nominal pore size to catch Phytophthora sporangia and zoospores. The filter was then cut into strips and placed filtrate side down on PARP. After 3 to 4 days, strips were removed and colonies of $P$. ramorum were counted, then recounted several times over the next 3 weeks as colonies emerged. One colony was used as an indication of one viable propagule of $P$. ramorum. Results were calculated in terms of CFU per liter (17).

Quantity and timing of inoculum production in rainwater was compared between the two sites using analysis of variance (ANOVA) to test the effects of site, rain date, and their interaction on CFU per liter. A separate analysis was used for each of the two rainy seasons. The ANOVA was weighted by the inverse of the standard deviation of the residuals squared $(41,60)$ because standard transformations did not control for unequal variances among treatment means as indicated by a Levene's Test (30).

Inoculum from individual infections on bay laurel leaves. To better compare the timing and quantity of inoculum production directly from bay laurel leaves in the two forest types, we quantified zoospores present on the leaf under natural forest conditions during rainstorms at the two sites approximately every 2 weeks throughout the rainy seasons of 2003-04 and 2004-05. At $\approx 24 \mathrm{~h}$ after the start of a rainstorm, when sporangia should have developed, a section of leaf, usually from the leaf tip, that contained the entire symptomatic region and a border of healthy-appearing tissue was cut from one leaf on each of 15 trees at each site and placed in a $2.0-\mathrm{ml}$ snap cap tube with $1.5 \mathrm{ml}$ of sterile deionized water. The leaf was placed with the upper side against the wall of the tube because sporangia form on the abaxial surface (J. M. Davidson, unpublished data). After the collection at a site was complete, vials were placed on ice for $45 \mathrm{~min}$ and then allowed to return to room temperature for $1 \mathrm{~h}$ to "shock" sporangia into releasing zoospores. The leaf tissue was removed to prevent further sporangia production, and tubes were incubated overnight at $20^{\circ} \mathrm{C}$ to allow zoospores to encyst so that the solution would be more uniform for counting. The next day, the solutions were vortexed and two 100- $\mu$ l aliquots were plated onto PARP. Colonies that grew from zoospores were counted at 24 and $48 \mathrm{~h}$. The average final count of the two plates was used to calculate the number of zoospores present in the $1.5 \mathrm{ml}$ of DI water and, consequently, on the leaf.

Quantity and timing of inoculum production on bay laurel leaves was compared between the mixed-evergreen and the redwood site using ANOVA to test the effects of site, rain date, and their interaction on number of spores per leaf. A separate analysis was used for each of the two rainy seasons, and the ANOVA was weighted as described in the "Inoculum in rainwater" section (see above).

New infections on bay laurel leaves. New infections indicate successful transmission and are essential for exponential increases in inoculum production during disease cycles. The timing of new infections is critical, especially if spring rains end early and sporulation ceases. To monitor the timing and final count of new infections in bay laurel leaves in the two forest types throughout the rainy seasons in 2003-04 (shortened) and 2004-05 (ex- tended), we marked 1,000 noninfected leaves at each site and then counted the leaves every 2 weeks during November to July to record whether leaves were infected. This study and analysis were done concurrently with the leaf abscission study (see Methods above for details). The time until infection of leaves in both forest types was compared using a proportional hazards survival analysis (30). The final infection count was compared between the two sites using a log-linear model evaluating the association between infection, abscission, and forest type (See Methods above). Separate analyses were used for both study years.

\section{RESULTS}

Multisite census. Infection and abscission of bay laurel leaves. Infection in bay laurel leaves at the five mixed-evergreen and six redwood sites occurred in both the 2001-02 and 2002-03 rainy seasons. For the purpose of these analyses, leaves that were missing before the first census or that were on branches that broke or were browsed by deer were excluded (2001-02: 40 leaves; 2002-03: 245 leaves). Omitting these leaves left 9,960 and 9,755 leaves in 2001-02 and 2002-03, respectively.

In 2001-02, 5.39\% $(241 / 4,474)$ and $4.36 \%(239 / 5,486)$ of leaves became infected by $P$. ramorum in mixed-evergreen and redwood forest, respectively. In 2002-03, 9.27\% (412/4,442) and $7.74 \%(411 / 5,313)$ became infected by $P$. ramorum in mixedevergreen and redwood forest, respectively. Other pathogens causing leaf necrosis also infected leaves. These included $P$. nemorosa, another Phytophthora sp. of ecological importance $(24,62)$. Percentages of other pathogens infecting leaves in the two forest types in 2001-02 were $2.79 \%(125 / 4,474)$ and $8.04 \%$ $(441 / 5,486)$ in mixed-evergreen and redwood forest, respectively; and, in 2002-03, were $4.64 \%(206 / 4,442)$ and $17.75 \%$ $(943 / 5,313)$, respectively. In 2001-02, P. nemorosa infected $0.04 \%(2 / 4,474)$ and $2.53 \%(139 / 5,486)$ of leaves in mixedevergreen and redwood forest, respectively; and $0.00 \%(0 / 4,442)$ and $3.78 \%(201 / 5,313)$ in 2002-03. Two redwood sites, Henry Cowell State Park (HC) and Muir Woods (MW), had very high levels of P. nemorosa (2001-02: HC, 10.21\%; MW, 3.71\%; 200203: HC, $15.64 \%$; MW, 4.98\%), whereas all other sites, with the exception of China Camp, a mixed-evergreen site, in 2001-02 (two infected leaves) had no incidence.

$P$. ramorum and other pathogens did not commonly co-occur in the same leaf (2001-02: 11/9,960 co-infections; 2002-03: 20/9,754 co-infections). Due to the disassociation of pathogen types, in both years, zero counts occurred for 1 of the 16 treatment combinations of a four-way log-linear model with main effects abscission, infection by $P$. ramorum, infection by other pathogens, and forest type. Consequently, this model would not converge. In addition, infection by other pathogens was strongly associated with leaf abscission (2001-02: infected, abscised = $27.03 \%$ versus uninfected, abscised $=5.22 \% ; 2002-03$ : infected, abscised $=26.98 \%$ versus uninfected, abscised $=9.53 \%$ ). To avoid confounding the statistical test of the interaction of abscission and $P$. ramorum infection for leaves that were not infected by $P$. ramorum but were infected by other pathogens, thus increasing their chance of abscission, leaves that were infected by other pathogens were excluded from analysis. Excluding these leaves left 9,394 and 8,606 samples in 2001-02 and 2002-03, respectively. A three-way log-linear model then was used to examine the association between abscission, infection by $P$. ramorum, and forest type.

In both seasons, a leaf that was infected with $P$. ramorum was far more likely to abscise than a noninfected leaf (2001-02: 46.27 versus 3.06\%; 2002-03: 46.45 versus 5.73\%) (Table 1). In both seasons, overall abscission rates were significantly higher in mixed-evergreen forest (2001-02: 7.50 versus 3.25\%; 2002-03: 10.84 versus $8.26 \%$ ) (Table 1 ). A leaf infected by $P$. ramorum was more likely to be shed in mixed-evergreen forest than in redwood 
forest during both study years (2001-02: 54.27 versus $38.30 \%$, $\chi^{2}=12.09$, df $=1, P=0.0005, n=469 ; 2002-03: 54.90$ versus $37.72 \%, \chi^{2}=23.94$, df $=1, P<0.0001, n=803$ ). An uninfected leaf was more likely to abscise in mixed-evergreen forest during 2001-02 (4.84 versus $\left.1.54 \%, \chi^{2}=83.08, P<0.0001, n=8,925\right)$, although abscission rates of uninfected leaves in the two forest types during 2002-03 were not significantly different (6.14 versus $\left.5.33 \%, \chi^{2}=2.34, P=0.1258, n=7,803\right)$. The probability of a leaf being infected by $P$. ramorum was significantly and slightly higher in mixed-evergreen forest for 2001-02 (5.38 versus $4.66 \%$ ), but not significantly different for 2002-03 (9.63 versus 9.04\%) (Table 1).

The experiment to test for negative effects of leaf tissue removal showed no effect of removing leaf tissue on leaf abscission. For analysis, 11 leaves in the uninfected categories were excluded because they became infected during the course of the experiment. Of the noninfected leaves, $15.05 \%$ (14/93) with wound and $18.75 \%(18 / 96)$ without wound abscised. Of the infected leaves, $79.0 \%$ (79/100) with wound and 83.0\% (83/100) without wound abscised. These differences were reflected in the nominal logistic analysis, in which the effect of infected on abscission was highly significant $\left(\chi^{2}=173.39\right.$, df $\left.=1, P<0.00001\right)$ but the effect of wounding $\left(\chi^{2}=0.98, \mathrm{df}=1, P=0.3231\right)$ and the interaction between infected and wounded $\left(\chi^{2}<0.0001\right.$, df $=1$, $P=0.9950$ ) were not significant.

Paired-site study. Summer survival. Pathogen recovery from attached and abscised leaves. Survival of $P$. ramorum as measured by recovery in bay laurel leaves during the summer months was significantly affected by whether the leaf abscised and by the forest type in which the leaf was growing (abscission: $\chi^{2}=405.37$, df $=1, P<0.00001$; forest type: $\chi^{2}=32.37$, df $=1$, $P<0.00001)$. In addition, the forest type $\times$ abscission interaction was significant $\left(\chi^{2}=8.57, \mathrm{df}=1, P<0.0034\right)$, indicating that the magnitude of the difference in recovery from attached versus abscised leaves differed in the two forest types (Fig. 1). We used $\chi^{2}$ analyses with a standard Bonferoni correction to investigate the effects of individual treatment levels on pathogen recovery. In both forest types, recovery was drastically reduced from bay laurel leaves that abscised (mixed-evergreen: 51.78 versus $15.33 \%, \chi^{2}=139.61, P<0.0001$; redwood: 74.00 versus $19.78 \%$, $\left.\chi^{2}=280.85, P<0.0001\right)$. By the end of the summer dry season, recovery from abscised leaves was $<3 \%$ at both sites, and often $0 \%$ at the mixed-evergreen site (Fig. 1). In addition, recovery from attached leaves was significantly less in the mixed-evergreen forest, indicating that recovery declined from attached bay laurel leaves in mixed-evergreen forest at a faster rate than in redwood forest throughout the summer $\left(74.00\right.$ versus $51.78 \%, \chi^{2}=48.16$, $P<0.0001)$. There was no significant difference in recovery from abscised leaves in the two forest types (mixed-evergreen 15.33 versus redwood $19.78 \%, \chi^{2}=3.08, P=0.08$ ) (Fig. 1).

Abscission rates of infected leaves. Infection levels were low at both sites in 2003-04, a year with shortened spring rains (mixedevergreen: 2/1,000 leaves; redwood: 86/1,000 leaves) (see Results: "New infections on bay laurel leaves"), preventing a comparison of abscission rates between mixed-evergreen and redwood forest sites. In 2004-05, a year with extended spring rains, high levels of infection at both sites (mixed-evergreen: 553/1,000 leaves; redwood: 636/1,000 leaves) allowed for tracking of leaf

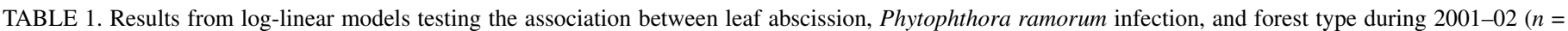
9,394) and 2002-03 $(n=8,606)$ for the multisite study ${ }^{\mathrm{a}}$

\begin{tabular}{|c|c|c|c|c|c|}
\hline \multirow[b]{2}{*}{ Effect } & \multirow[b]{2}{*}{ df } & \multicolumn{2}{|c|}{$2001-02$} & \multicolumn{2}{|c|}{$2002-03$} \\
\hline & & Likelihood ratio $\chi^{2}$ & $P$ & Likelihood ratio $\chi^{2}$ & $P$ \\
\hline Abscission $\times P$. ramorum & 1 & 739.48 & $<0.0001$ & 828.89 & $<0.0001$ \\
\hline Abscission $\times$ forest type & 1 & 63.99 & $<0.0001$ & 24.02 & $<0.0001$ \\
\hline P. ramorum $\times$ forest type & 1 & 10.70 & 0.0011 & 0.12 & 0.7275 \\
\hline Abscission $\times P$. ramorum $\times$ forest type & 1 & 5.21 & 0.0225 & 10.03 & 0.0015 \\
\hline
\end{tabular}

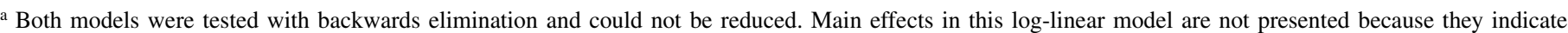
differences in sample sizes across levels of that category, and are not of primary interest to the questions tested in this analysis.
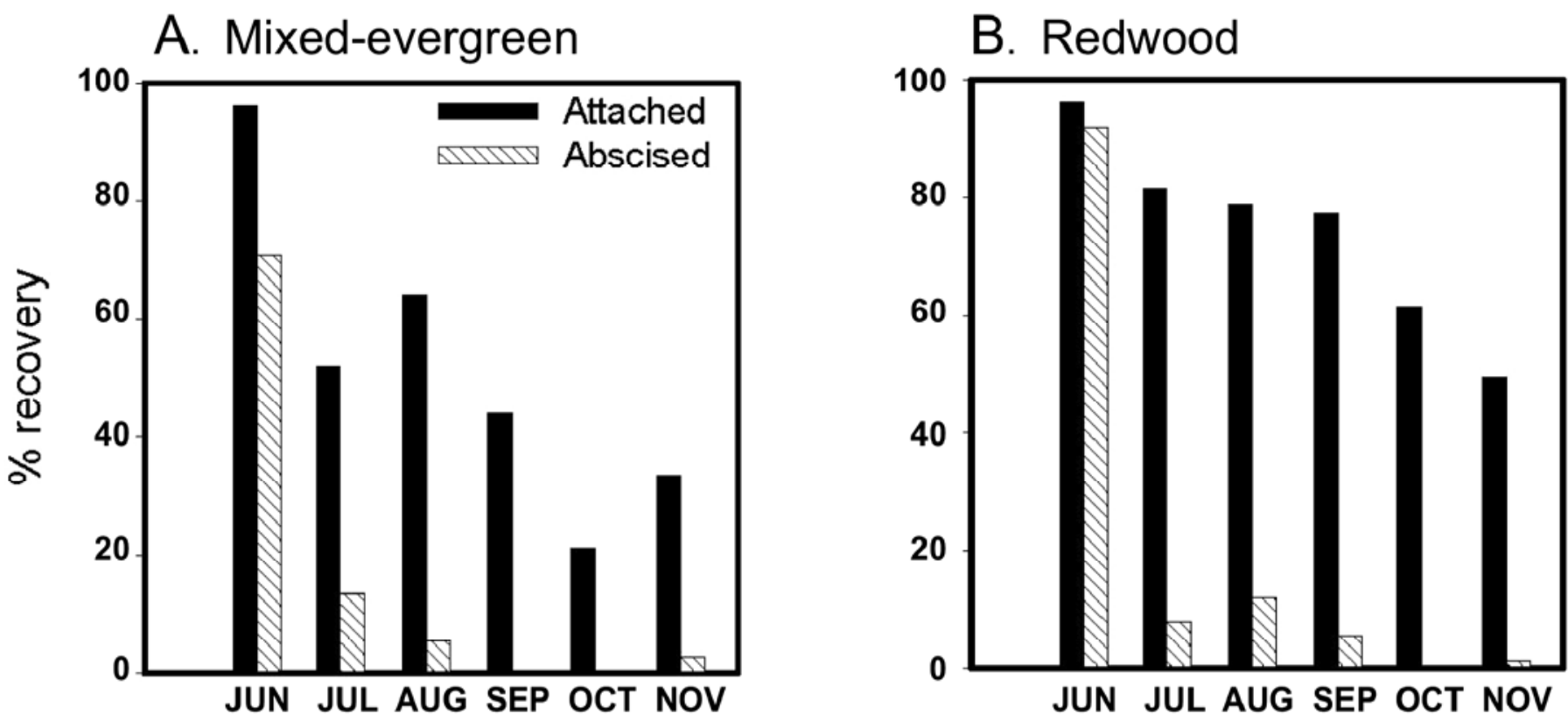

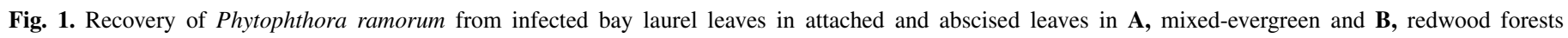
throughout the summer dry season of 2003. 
abscission throughout the rainy season and summer dry season. Using log-linear analysis to evaluate the association between abscission, infection, and forest type, a two-way model was selected by backwards elimination of terms from the full, threeway model, and was determined to be the best fit for the data through comparison of likelihood ratio $\chi^{2}$ values with the more saturated model. A leaf that was infected by $P$. ramorum was much more likely to abscise than an uninfected leaf (25.99 versus $3.45 \%$ ) (Table 2). Overall leaf abscission was greater in mixedevergreen forest (24.40 versus $9.30 \%$ ) (Table 2). For both infected and uninfected leaves, abscission was more likely to occur in mixed-evergreen than in redwood forest (infected: 39.96 versus $13.84 \%, \chi^{2}=106.92, P<0.0001$; uninfected: 5.15 versus $1.37 \%$, $\left.\chi^{2}=9.43, P=0.0021\right)$. The nonsignificance of the three-way term in the log-linear model indicates that the magnitude of the difference in abscission rates between infected and noninfected leaves did not change significantly with forest type. The graphical presentation of the data shows that, regardless of infection status or forest type, leaf abscission occurred predominantly during the summer dry season (Fig. 2).

Leaf water potential. Leaf water potential was significantly higher in bay laurel leaves from redwood forest than from mixedevergreen forest at the end of the summer in both 2004 and 2006 (2004: $-17.37 \pm$ standard error [SE] 0.78 versus $-21.54 \pm$ SE 0.90 barr; $t=3.50, P<0.0016 ; 2006:-13.75 \pm$ SE 0.41 versus -17.93 \pm SE 0.72 barr; $t=5.06, P<0.0001$ ). We excluded four and two samples from the 2004 and 2006 data, respectively, due to disruption of the airtight seal surrounding twigs of larger diameters.

Winter inoculum production and infection. Inoculum in rainwater. For the purpose of statistical comparison of rainwater

TABLE 2. Two-way interactions from a reduced, two-way log-linear model evaluating the association between leaf abscission, Phytophthora ramorum infection, and forest type for the paired-site study $(n=2,000)$ during 2004-05, a year with extended spring rains

\begin{tabular}{lcrc}
\hline Effect & df & $\chi^{2}$ & $P$ \\
\hline Abscission $\times$ P. ramorum infection & 2 & 240.54 & $<0.0001$ \\
Abscission $\times$ forest type & 2 & 116.36 & $<0.0001$ \\
$P$. ramorum infection $\times$ forest type & 2 & 46.81 & $<0.0001$ \\
\hline
\end{tabular}

inoculum levels in both forest types, we excluded sample dates at the beginning or end of the rainy seasons for which all samples at both sites were zero because conditions may not have been appropriate for spore production. Dates for which only one of the sites failed to produce spores were included in analyses, leaving 7 and 12 sample dates in 2003-04 and 2004-05, respectively. To meet the assumptions of ANOVA, 0.1 was added to 1 of the 15 samples at the mixed-evergreen site for sample dates (cells) in which all samples were zero (one date in 2003-04 and three dates in 2004-05). This addition was conservative, because it lowered the difference in CFU per liter between the mixed-evergreen and the redwood site. Mean inoculum production in redwood forest was significantly greater than in mixed-evergreen forest for both years (2003-04: LSM 19.69 \pm SE 4.60 versus $3.91 \pm$ SE 0.94 CFU/liter; $F=11.30, \mathrm{df}=1, P=0.0009 ; 2004-05$ : LSM $53.96 \pm$ 10.98 versus $11.80 \pm \mathrm{SE} 4.97 \mathrm{CFU} /$ liter; $F=12.24$, df $=1, P=$ 0.0005 (Fig. 3A and B). Inoculum levels also differed significantly among rain dates in each season (all $P<0.0001$ ). The significant interaction of rain date $\times$ forest type (all $P<0.02$ ) in both seasons indicated that the difference in inoculum levels between the forest types varied across rain dates. In both 2003-04 and 2004-05, peaks in inoculum production occurred earlier in the rainy season in redwood forest than in mixed-evergreen forest (Fig. 3A and B). In addition, extended rains in 2004-05 led to a longer period of inoculum production in both forest types. In mixed-evergreen forest, higher levels of inoculum only occurred with extended spring rains at the end of 2004-05 (Fig. 3A and B).

Inoculum from individual infections on bay laurel leaves. For the purpose of analysis, rain dates were excluded if no samples produced spores. In addition, in the low rainfall year, 2003-04, two rain events were excluded because plant parts dried before they could be collected. These exclusions left six and eight sample dates for analysis in 2003-04 and 2004-05, respectively. To meet the assumptions of ANOVA, 1 was added to 1 of the 15 samples at the mixed-evergreen site for sample dates (cells) in which all samples were zero (two dates in 2003-04 and one date in 2004-05). This addition was conservative, because it lowered the difference in CFU per liter between the mixed-evergreen and the redwood site. Zoospores per leaf were significantly higher in redwood forest in 2003-04 (LSM 267.47 \pm SE 58.46 versus $28.52 \pm \mathrm{SE} 13.93$ spores; $F=15.81, \mathrm{df}=1, P=0.0001$ ) but not in

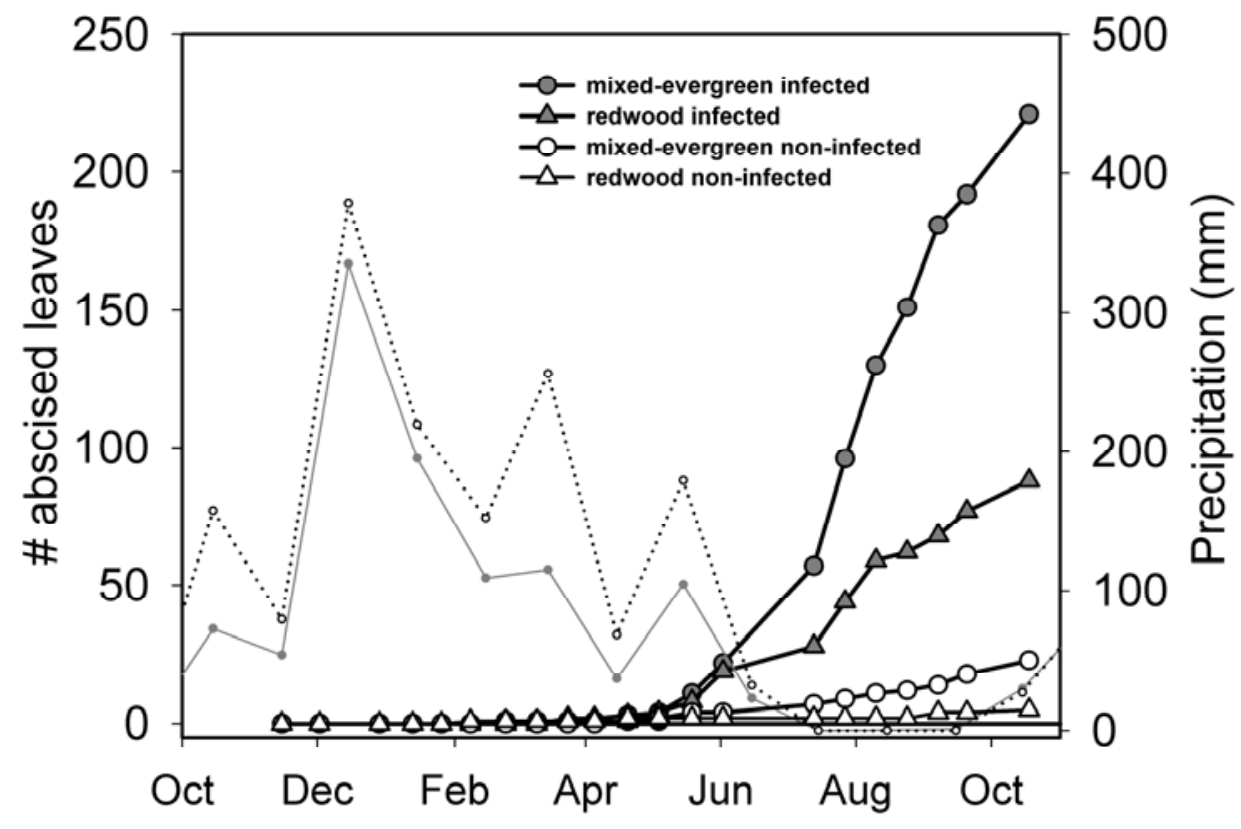

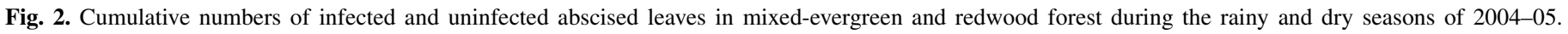

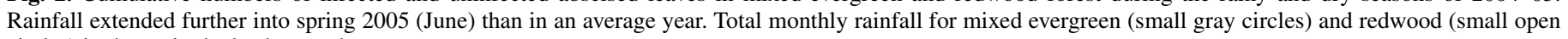
circles) is shown in the background. 
2004-05 (LSM redwood 1,019.12 \pm 218.98 versus LSM mixedevergreen 638.34 \pm SE 139.36; $F=2.15$, df $=1, P=0.1438$ ) (Fig. $3 \mathrm{C}$ and D). Zoospores per leaf differed significantly among rain dates in both seasons (all $P<0.006$ ). The rain date $\times$ forest type interaction was significant in 2003-04 $(P=0.0004)$ but not in 2004-05 $(P=0.2427)$, indicating that the magnitude of the differ- ence in zoospores per leaf at the two sites varied significantly in the shortened but not the extended spring rainy season. In redwood forest, peaks in zoospore production occurred early in both years. In mixed-evergreen forest, levels of zoospore production remained more constant across the seasons (Fig. 3C and D). Consistent with the results for inoculum in rainwater, greater

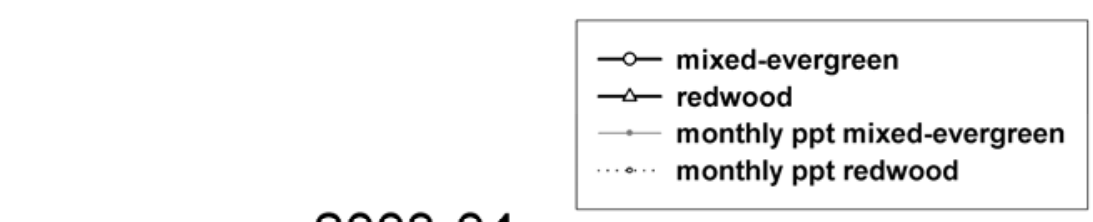

2003-04

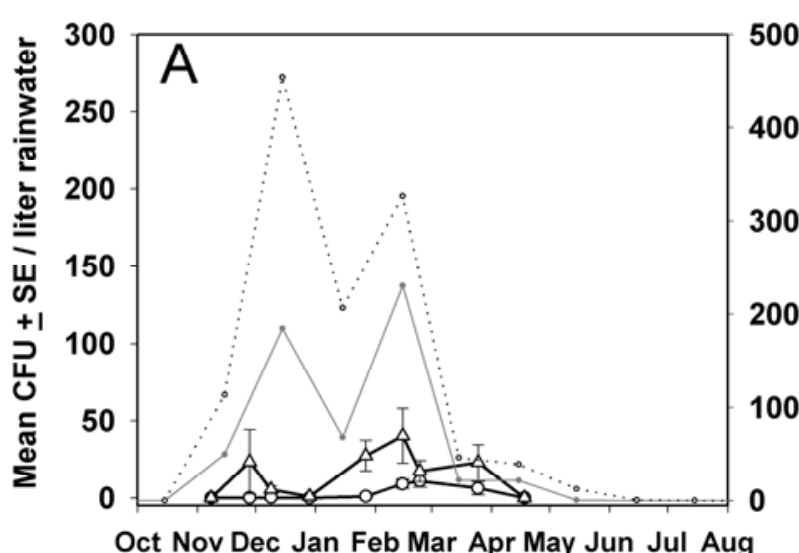

Oct Nov Dec Jan Feb Mar Apr May Jun Jul Aug
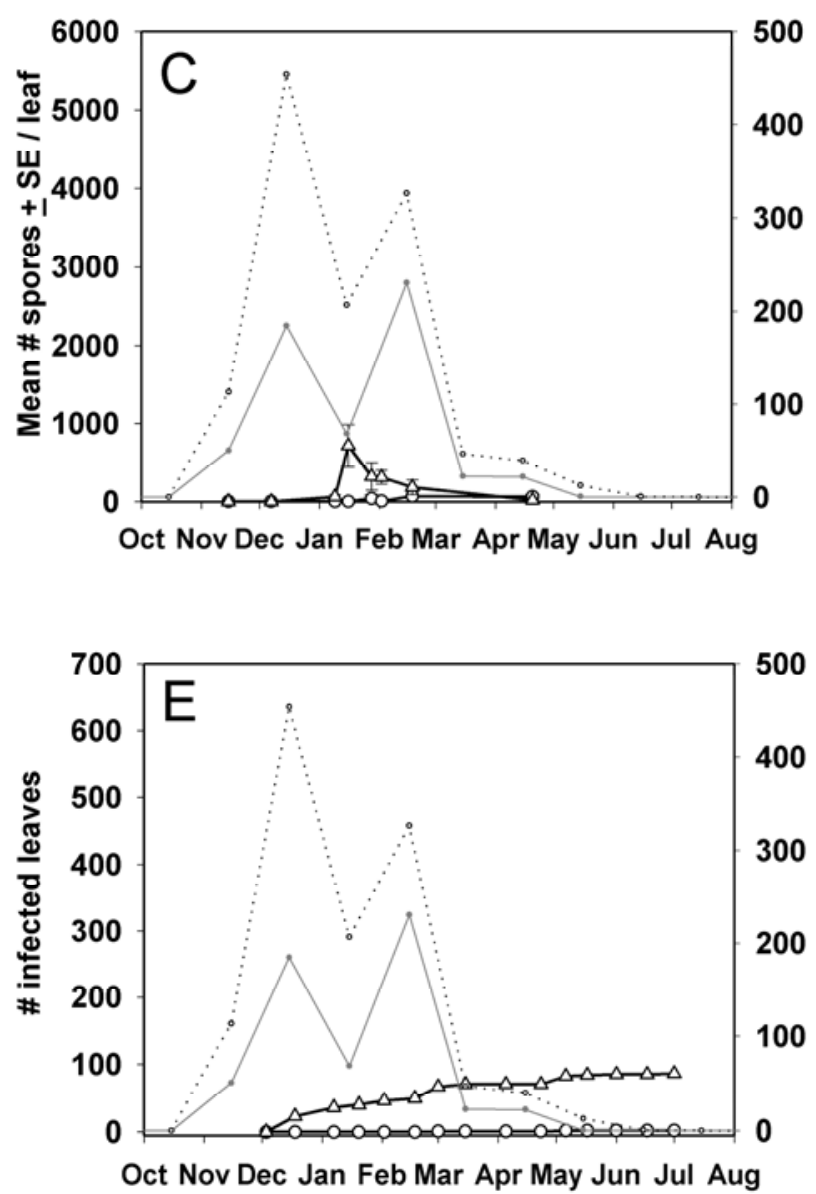

2004-05

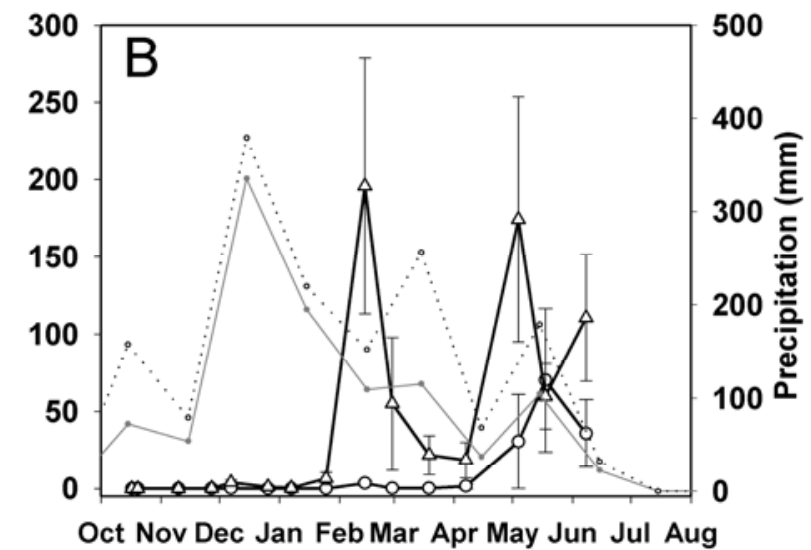

Oct Nov Dec Jan Feb Mar Apr May Jun Jul Aug
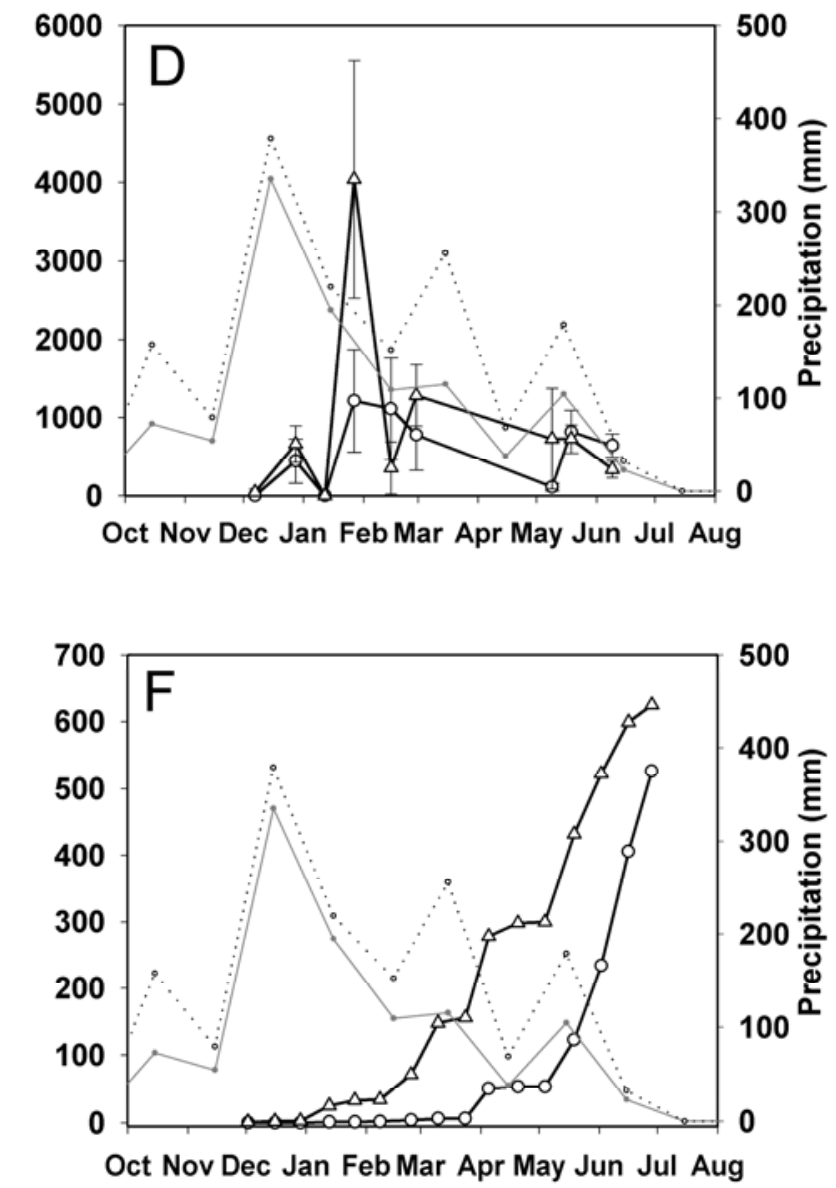

Fig. 3. Timing and quantity of $\mathbf{A}$ and $\mathbf{B}$, inoculum in rainwater; $\mathbf{C}$ and $\mathbf{D}$, inoculum produced on bay laurel leaves (zoospores/leaf); and $\mathbf{E}$ and $\mathbf{F}$, number of new infections on bay laurel leaves in mixed-evergreen versus redwood forest sites. Total monthly rainfall ( $\mathrm{mm}$ ) for both sites is also plotted for the 2003-04 and 200405 rainy seasons. 
rainfall in 2004-05 led to a 17.85- and 5.65-fold increase in peak mean zoospore production for mixed-evergreen and redwood forest, respectively.

New infections on bay laurel leaves. Time until infection occurred earlier in redwood forest as opposed to mixed-evergreen forest. In 2003-04, a year with shortened spring rainfall, low levels of infection at the mixed-evergreen site (2/1,000 leaves) prevented statistical analysis of timing of infection. However, $86 / 1,000$ leaves became infected in redwood forest during this time period, demonstrating earlier infection for redwood forest in this year. In 2004-05, a year with extended spring rains, high levels of infection allowed for statistical comparison of timing of infection between the sites with a proportional hazards analysis. Infection occurred earlier in redwood forest $\left(\chi^{2}=153.37, \mathrm{df}=1\right.$, $P<0.0001$ ) (Fig. 3E and F).

In 2003-04, low numbers of infection at the mixed-evergreen site prevented the use of a log-linear model with effects abscission, infection, and forest type to compare final infection counts for the two forest types. Consequently, the final infection counts were compared with a likelihood ratio $\chi^{2}$ test. Infection counts were significantly higher at the redwood site $\left(\chi^{2}=105.59, P<\right.$ $0.0001)$. In conjunction with the abscission study, final infection counts for 2004-05 were compared for the two forest types in a log-linear model with effects of abscission, infection, and forest type (see Methods and Results for "Abscission rates of infected leaves"). Infection was significantly greater in redwood forest (63.60 versus $55.30 \%$ ) (Table 2; Fig. 3E and F). Consistent with the inoculum studies, new infections were greatly increased in 2004-05 over 2003-04 at both sites (Fig. 3E and F). Isolation of other Phytophthora spp. during the two seasons was extremely low: P. nemorosa was isolated from only 1 of 1,540 bay laurel leaves cultured.

\section{DISCUSSION}

For $P$. ramorum and bay laurel, fine-scale host $\times$ pathogen interactions varied with forest type in both the summer dormant and winter reproductive seasons in California oak woodlands. In a detailed, paired-site study, we compared transmission from bay laurel leaves in a mixed-evergreen and redwood forest that shared similar weather patterns and invasion history. These two sites had low levels of other foliar pathogens that would potentially confound comparisons of $P$. ramorum transmission. We found that summer survival of $P$. ramorum in bay laurel leaves was lower in mixed-evergreen forest. As the summer progressed, recovery of $P$. ramorum from attached, infected bay laurel leaves declined at a faster rate in mixed-evergreen than in redwood forest (Fig. 1). In addition, abscission rates of infected leaves were higher at the mixed-evergreen site, consistent with results from the multisite survey. In the paired-site study, recovery of $P$. ramorum from abscised leaves in the leaf litter at the end of summer was near zero even after 4 months of incubation (Fig. 1), indicating that survival was greatly reduced in abscised leaves, or that breaking dormancy from dried leaves may require longer than 4 months. Four months is often longer than the duration of the rainy season in central, coastal California. Therefore, both lower recovery from infected leaves that remained attached and higher abscission rates of infected leaves led to lower summer survival of $P$. ramorum in mixed-evergreen forest.

Lower summer survival of $P$. ramorum from these two causes may underlie the relative delay in inoculum production and new infections during the winter rainy season at the mixed-evergreen versus the redwood site in the paired-site study, ultimately leading to lower inoculum levels and fewer new infections in this forest type. Although inoculum and infection levels were more similar for the two sites at the end of a longer than average spring rainy season in 2004-05, the delayed onset in inoculum production suggests that inoculum production and new infections on bay laurel leaves are likely to be low in mixed-evergreen forest in years such as 2003-04, when rains end earlier than normal. Even in average years, when rains extend through April, inoculum levels and new infections in mixed-evergreen forest may only be entering a period of exponential growth when rains stop (Fig. 3).

Although earlier onset of inoculum production resulted in higher levels of infection in the redwood forest for both seasons of the paired-site study, results from the multisite survey indicated that final infection counts on bay laurel leaves at a site, a measure of transmission success, represent a more complicated ecological process. In contrast to the paired-site study, the probability of a leaf being infected in redwood forest was slightly lower than in mixed-evergreen forest in 2001-02 and not significantly different in 2002-03. Although the darker, wetter conditions of redwood forest favored $P$. ramorum, they also supported growth of other foliar pathogens, including $P$. nemorosa, that appeared to competitively exclude $P$. ramorum and lower $P$. ramorum infection levels at some redwood sites in the multisite study. Therefore, final infection counts at a site will depend not only on forest type but also on invasion history of $P$. ramorum and other pathogens.

Pathogen biology leading to earlier onset of inoculum production and higher inoculum levels in throughfall rainwater at the redwood site in the paired-site study may involve not only greater numbers of leaves with viable $P$. ramorum populations but also higher pathogen fitness from individual leaf infections. Greater summer survival of $P$. ramorum in redwood forest resulted in more leaves with viable $P$. ramorum populations to produce infective spores when winter rains began. Subsequent new leaf infections occurring earlier in redwood forest further increased the difference in number of leaf infections contributing to the inoculum pool at the two forest sites. In addition, at the redwood forest site, greater numbers of spores were produced per individual leaf infection in 2003-04, and a tendency toward higher production of spores per leaf occurred in 2004-05, especially early in the season (Fig. 3C and D). Higher spore counts per leaf infection in redwood forest could be due to greater survival of $P$. ramorum biomass per leaf during the summer or an earlier emergence from dormancy in these less moisture-stressed populations. In addition, reproduction from new infections in redwood forest are likely to have more viable mycelia and produce more spores than infections from the previous season in either forest type. Winter conditions in redwood forest such as higher moisture levels may also contribute to greater spore production from bay laurel leaf infections in this forest type.

Microclimate differences in light and moisture availability between the two forest types may underlie the differences in transmission dynamics in the summer survival and subsequent winter infective seasons (Dileo, unpublished data). For example, greater canopy openness and lowered contiguous forest are associated with lower relative humidity and fewer infected bay laurel leaves in mixed-evergreen forest (15). Furthermore, our paired-site study showed lower water potential in bay laurel leaves from the mixed-evergreen forest at the end of both summer dry seasons studied. Although studies are still in progress, chlamydospores on leaves and hyphae within leaves are thought to be P. ramorum survival structures (20) (J. Parke, unpublished data). Lower water potential in bay laurel leaves in mixed-evergreen forest may lead to decreased summer survival of $P$. ramorum hyphae and chlamydospores or a deeper dormancy that requires a longer time period to break. Higher light levels in mixedevergreen forest also may cause greater desiccation and ultraviolet damage to chlamydospores on the leaf surface.

Higher light levels also may allow for higher abscission rates at mixed-evergreen sites, resulting in a greater loss of reservoir inoculum during the summer. Abscission rates of infected leaves were 1.4 to 2.6 times higher in mixed-evergreen forest compared with redwood forest in the multisite and paired-site studies. Results from other research indicate that bay laurel leaves in the 
mixed-evergreen and redwood forests of our paired-site study exhibit different gross morphologies, with leaves at the mixedevergreen site measuring significantly smaller in area (mixedevergreen: $11.30+0.35 \mathrm{~cm}^{2}$ versus redwood: $19.16+0.73 \mathrm{~cm}^{2}$ ) (E. Fichtner, unpublished data). Greater abscission rates of these smaller leaves in the higher light environment are consistent with global trends in leaf traits that show leaf longevity decreasing with specific leaf area and photosynthetic capacity as part of a life history strategy that entails higher growth rates, lower allocation to chemical or structural defenses, and a flexible growth response to sun patches or leaf damage that involves turnover of plant parts $(6,10,13,46,63)$.

When infected by $P$. ramorum, leaves in our studies were 7 to 25 times more likely to be shed than uninfected leaves, depending on forest type and year. Results from the hole-punch experiment were consistent with this outcome: Leaves were shed if they lost tissue due to infection by $P$ ramorum, not from damage due to wounding alone. Therefore, abscission appears to be a defense by bay laurel against pathogens, and trees in the higher light environment of mixed-evergreen forest may use this defense mechanism more than trees in redwood forest because they can more readily replace leaves (13).

Abscission rate may be a key factor for predicting timing of onset of winter inoculum production and new infections at a given forest site. Although abscission rates in both the paired and multisite study were associated with mixed-evergreen or redwood forest types that have categorically different light and moisture conditions, within both of these forest types, a range of light and moisture conditions exists $(4,42)$. Presumably, these environmental conditions lead to variation in abscission rates and, therefore, differences in pathogen summer survival not only between but also within forest type. Additional studies are needed to investigate whether readily measured surrogates for abscission rate, such as specific leaf area, would be useful predictors of timing of onset of winter inoculum production at a given forest site.

The effect of the delayed onset of inoculum production and new infections in mixed-evergreen forest relative to redwood forest can potentially extend into subsequent dry and rainy seasons $(16,17)$. In mixed-evergreen forest during years with average or low spring rainfall, lower inoculum levels may result in fewer leaf infections as well as lower pathogen biomass per infection. These conditions will further decrease survival of reservoir inoculum in bay laurel leaves during the following summer (DiLeo, unpublished data) and, consequently, affect inoculum and new infection buildup in the next rainy season. The long-term effects of short rainy seasons on $P$. ramorum populations in these two forest types are unknown, and studies are needed to determine the extent to which $P$. ramorum populations are decreased in the forest canopy after several unfavorable years, especially in mixed-evergreen forests dominated by bay laurel or other foliar hosts with relatively short leaf life spans.

This study highlights the importance of annual variation in rainfall for the course of the $P$. ramorum epidemic in different forest types. In years with low rainfall, $P$. ramorum may still spread at low rates and infect tanoak in redwood forest, whereas these years may not show much progression of disease on bay laurel or coast live oak in mixed-evergreen forest. Years with extended rains show dramatically increased transmission in both forest types that result in episodic pulses of large numbers of infected oak and tanoak trees $(17,47,49)$, and are the years in which significant spread to oak trees appears to occur in mixedevergreen forest. This heterogeneity in years and responses in pathogen transmission will affect the dynamics and shape of invasion in the two forest types.

Our study found that fine-scale interactions of transmission differed for $P$. ramorum and its main driver host, bay laurel, in two of the most common forest types in the range of the pathogen in central coastal California. Summer survival of $P$. ramorum was lower in bay laurel leaves in drier, more open mixed-evergreen forests than in redwood forests. This was due to lower recovery from attached leaves, as well as higher abscission rates of infected leaves that resulted in virtually no recovery of the pathogen from dried leaves in the leaf litter by the end of the summer. Lower summer survival of reservoir inoculum in bay laurel leaves led to delayed onset of both inoculum production and new infections in mixed-evergreen forest. Predicting transmission patterns in these forests can be confounded by competition from other foliar pathogens, especially in redwood forest. However, in forests where $P$. ramorum is the main foliar pathogen, the earlier onset of inoculum production and new infections in redwood forest may lead to greater inoculum pressure on vulnerable tanoak trees even in lowrainfall years. Ultimately, the heterogeneity in forest type across the coastal mountain range of $P$. ramorum in California may lead to differences in invasion speed, disease dynamics, and co-evolution of host and pathogen in these forest types.

\section{ACKNOWLEDGMENTS}

We thank the California State Parks, Marin Municipal Water District, Marin Open Space District, Muir Woods National Monument, Skyline Park, the Schneider Family, and especially Jack London State Park, the Sonoma Developmental Center, and Fairfield Osborn Preserve for permission to conduct research in their forests; Jack London State Park, J. Clothier, and P. Maloney for contributing rainfall data; K. Falk, A. Adie, R. Albright, J. Bienapfl, K. Covington, K. Crandall, C. Friel, L. Douhan, K. Huryn, C. Jensen, S. Kane, S. Langley, S. Lynch, G. Slaughter, M. Voigt, G. Walden, and J. Zanzot for providing superb assistance; T. Swiecki and E. Bernhardt for excellent work with the pressure bomb; D. Carlon, D. Hüberli, and two anonymous reviewers for constructive comments that improved the manuscript; and the United States Department of Agriculture Forest Service Pacific Southwest Research Station, the Gordon and Betty Moore Foundation, and NSF-NIH Ecology of Infectious Diseases program EF-0622770 for funding.

\section{LITERATURE CITED}

1. APHIS. 2010. APHIS List of Regulated Hosts and Plants Associated with Phytophthora ramorum. Published online by APHIS/USDA. http:// www.aphis.usda.gov/ppq/ispm/pramorum.

2. Bahnweg, G., Heller, W., Stich, S., Knappe, C., Betz, G., Heerdt, C., Kehr, R. D., Ernst, D., Langebartels, C., Nunn, A. J., Rothenburger, J., Schubert, R., Wallis, P., Muller-Starck, G., Werner, H., Matyssek, R., and Sandermann, H. 2005. Beech leaf colonization by the endophyte Apiognomonia errabunda dramatically depends on light exposure and climatic conditions. Plant Biol. 7:659-669.

3. Barbour, M. G., and Billings, W. D., eds. 2000. North American Terrestrial Vegetation. Cambridge University Press, Cambridge.

4. Barbour, M. G., and Major, J., eds. 1998. Terrestrial Vegetation of California. California Plant Society Press, Sacramento, CA.

5. Barrett, L. G., Thrall, P. H., and Burdon, J. J. 2007. Evolutionary diversification through hybridization in a wild host-pathogen interaction. Evolution 61:1613-1621.

6. Beaudet, M., and Messier, C. 1998. Growth and morphological responses of yellow birch, sugar maple, and beech seedlings growing under a natural light gradient. Can. J. For. Res. 28:1007-1015

7. Bos, M. M., Steffan-Dewenter, I., and Tscharntke, T. 2007. Shade tree management affects fruit abortion, insect pests and pathogens of cacao Agric. Ecosyst. Environ. 120:201-205.

8. Bradley, D. J., Gilbert, G. S., and Parker, I. M. 2003. Susceptibility of clover species to fungal infection: The interaction of leaf surface traits and environment. Am. J. Bot. 90:857-864.

9. California Soil Resource Lab. Published online by the University of California-Davis. http://casoilresource.lawr.ucdavis.edu/drupal/.

10. Chapin, F. S., Autumn, K., and Pugnaire, F. 1993. Evolution of suites of traits in response to environmental stress. Am. Nat. 142:S78- S92.

11. Chellemi, D. O., and Britton, K. O. 1992. Influence of canopy microclimate on incidence and severity of dogwood anthracnose Can. J. Bot. 70:1093-1096.

12. Chen, J., Saunders, S. C., Crow, T. R., Naiman, R. J., Brosofske, K. D., Mroz, G. D., Brookshire, B. L., and Franklin, J. F. 1999. Microclimate in forest ecosystem and landscape ecology. Bioscience 49:288-297.

13. Coley, P. D., Bryant, J. P., and Chapin, F. S., III. 1985. Resource 
availability and plant antiherbivore defense. Science 230:895-899.

14. Colhoun, J. 1973. Effects of environmental factors on plant disease. Annu. Rev. Phytopathol. 11:343-364.

15. Condeso, T. E., and Meentemeyer, R. K. 2007. Effects of landscape heterogeneity on the emerging forest disease sudden oak death. J. Ecol. 95:364-375.

16. Davidson, J. M., Patterson, H. A., and Rizzo, D. M. 2008. Sources of inoculum for Phytophthora ramorum in a redwood forest. Phytopathology 98:860-866.

17. Davidson, J. M., Wickland, A. C., Patterson, H. A., Falk, K. R., and Rizzo, D. M. 2005. Transmission of Phytophthora ramorum in mixedevergreen forest in California. Phytopathology 95:587-596.

18. Davis, F. W., Stine, P. A., Stoms, D. M., Borchert, M. I., and Hollander, A. D. 1995. Gap analysis of the actual vegetation of California: I. the southwest region. Madrona 42:40-78.

19. Erwin, D. C., and Ribeiro, O. K. 1996. Phytophthora Diseases Worldwide. American Phytopathological Society Press, St. Paul, MN.

20. Fichtner, E. J., Lynch, S. C., and Rizzo, D. M. 2007. Detection, distribution, survival, and sporulation of Phytophthora ramorum in a California redwood-tanoak forest. Phytopathology 97:1366-1375.

21. Garbelotto, M., Davidson, J. M., Ivors, K., Maloney, P. E., Huberli, D., Koike, S. T., and Rizzo, D. M. 2003. Non-oak native plants are main hosts for sudden oak death pathogen in California. Calif. Agric. 57:18-23.

22. Gilbert, G. S., Reynolds, D. R., and Bethancourt, A. 2007. The patchiness of epifoliar fungi in tropical forests: Host range, host abundance, and environment. Ecology 88:575-581.

23. Gilles, T., Fitt, B. D. L., Kennedy, R., Welham, S. J., and Jeger, M. J. 2000. Effects of temperature and wetness duration on conidial infection, latent period and asexual sporulation of Pyrenopeziza brassicae on leaves of oilseed rape. Plant Pathol. 49:498-508.

24. Hansen, E. M., Reeser, P., Davidson, J. M., Garbelotto, M., Ivors, K., Douhan, L., and Rizzo, D. M. 2003. Phytophthora nemorosa, a new species causing cankers and leaf blight of forest trees in California and Oregon, U.S.A. Mycotaxon 88:129-138.

25. Ivors, K. L., Hayden, K. J., Bonants, P. J. M., Rizzo, D. M., and Garbelotto, M. 2004. AFLP and phylogenetic analyses of North America and European populations of Phytophthora ramorum. Mycol. Res. 108:378-392.

26. Johnson, D. A., Alldredge, J. R., and Vakoch, D. L. 1996. Potato late blight forecasting models for the semiarid environment of south-central Washington. Phytopathology 86:480-484.

27. Jung, T., Hansen, E. M., Winton, L. M., Osswald, W., and Delatour, C. 2002. Three new species of Phytophthora from European oak forests. Mycol. Res. 106:397-411.

28. Kelly, N. M., and Meentemeyer, R. K. 2002. Landscape dynamics of the spread of sudden oak death. Photogramm. Eng. Rem. Sens. 68:10011009.

29. Kennelly, M. M., Gadoury, D. M., Wilcox, W. F., Magarey, P. A., and Seem, R. C. 2005. Seasonal development of ontogenic resistance to downy mildew in grape berries and rachises. Phytopathology 95:14451452 .

30. Levene, H. 1960. Robust tests for equality of variance. Pages 278-292 in: Contributions to Probability and Statistics. I. Olkin, ed. Stanford University Press, Palo Alto, CA.

31. Maloney, P. E., Lynch, S. C., Kane, S. F., Jenson, C. E., and Rizzo, D. M. 2005. Establishment of an emerging generalist pathogen in redwood forest communities. J. Ecol. 93:899-905

32. Manos, P. S., Cannon, C. H., and Oh, S.-H. 2008. Phylogenetic relationships and taxonomic status of the paleoendemic Fagaceae of western North America: Recognition of a new genus, Notholithocarpus. Madroño 55:181-190.

33. Manter, D. K., Reeser, P. W., and Stone, J. K. 2005. A climate-based model for predicting geographic variation in Swiss needle cast severity in the Oregon Coast Range. Phytopathology 95:1256-1265.

34. Marcais, B., Dupuis, F., and Desprez-Loustau, M. L. 1996. Modelling the influence of winter frosts on the development of the stem canker of red oak, caused by Phytophthora cinnamomi. Ann. Sci. For. 53:369-382.

35. Matthes, U. 2006. Microsite and climactic controls of tree population dynamics: An 18-year study on cliffs. J. Ecol. 94:402-414

36. McElrone, A. J., Reid, C. D., Hoye, K. A., Hart, E., and Jackson, R. B. 2005. Elevated $\mathrm{CO} 2$ reduces disease incidence and severity of a red maple fungal pathogen via changes in host physiology and leaf chemistry. Global Change Biol. 11:1828-1836.

37. Meentemeyer, R. K., Rank, N. E., Anacker, B. L., and Cushman, J. H. 2008. Influence of land-cover change on the spread of an invasive forest pathogen. Ecol. Appl. 18:159-171.

38. Meentemeyer, R. K., Rank, N. E., Shoemaker, D. A., Oneal, C. B., Wickland, A. C., Frangioso, K., and Rizzo, D. M. 2008. Impact of sudden oak death on tree mortality in the Big Sur ecoregion of California. Biol. Invas. 10:1243-1255.
39. Morandi, M. A. B., Maffia, L. A., and Sutton, J. C. 2001. Development of Clonostachys rosea and interactions with Botrytis cinerea in rose leaves and residues. Phytoparasitica 29:103-113.

40. Mulder, C. P. H., Roy, B. A., and Gusewell, S. 2008. Herbivores and pathogens on Alnus viridis subsp. fruticosa in Interior Alaska: Effects of leaf, tree, and neighbour characteristics on damage levels. Botany 86:408421.

41. Neter, J., Wasserman, W., and Kutner, M. H. 1990. Applied Linear Statistical Models. Richard D. Irwin, Inc., Boston.

42. Noss, R. F., ed. 1999. The Redwood Forest: History, Ecology, and Conservation of the Coast Redwoods. Island Press, Washington, DC.

43. Orians, C. M., and Floyd, T. 1997. The susceptibility of parental and hybrid willows to plant enemies under contrasting soil nutrient conditions. Oecologia 109:407-413.

44. Panova, G. G., Grote, D., and Kläring, H. P. 2004. Population dynamics of Pythium aphanidermatum and response of tomato plants as affected by root-zone temperature. Z. Pflanzenkrankh. Pflanzenschutz 111:52-63.

45. Parke, J. L., and Lucas, S. 2008. Sudden oak death and ramorum blight. Online. The Plant Health Instructor doi:10.1094//PHI-I-2008-0227-01.

46. Reich, P., Ellsworth, D., Walters, M., Vose, J., Gresham, C., Volin, J., and Bowman, W. 1999. Generality of leaf trait relationships: A test across six biomes. Ecology 80:1955-1969.

47. Rizzo, D. M., and Garbelotto, M. 2003. Sudden oak death: Endangering California and Oregon forest ecosystems. Front. Ecol. Environ. 1:197204.

48. Rizzo, D. M., Garbelotto, M., Davidson, J. M., Slaughter, G. W., and Koike, S. T. 2002. Phytophthora ramorum as the cause of extensive mortality of Quercus spp. and Lithocarpus densiflorus in California. Plant Dis. 86:205-214.

49. Rizzo, D. M., Garbelotto, M., and Hansen, E. M. 2005. Phytophthora ramorum: Integrative research and management of an emerging pathogen in California and Oregon forests. Annu. Rev. Phytopathol. 43:309-335.

50. Roy, B. A., Gusewell, S., and Harte, J. 2004. Response of plant pathogens and herbivores to a warming experiment. Ecology 85:2570-2581.

51. SAS Institute. 2007. JMP 7. SAS Institute, Inc., Cary, NC.

52. Shuford, W. D., and Timossi, I. C. 1989. Plant Communities of Marin County. California Native Plant Society, Sacramento, CA.

53. Strengbom, J., Englund, G., and Ericson, L. 2006. Experimental scale and precipitation modify effects of nitrogen addition on a plant pathogen. J. Ecol. 94:227-233.

54. Swiecki, T. J., and Bernhardt, E. 2002. Evaluation of stem water potential and other tree and stand variables as risk factors for Phytophthora ramorum canker development in coast live oak. Pages 787-798 in: Proc. Fifth Symp. Oak Woodlands: Oak Woodlands in California's Changing Landscape, San Diego, CA. General Technical Report PSW-GTR-184. R. B. Standiford, D. McCreary and K. L. Purcell, eds. Pacific Southwest Research Station, Forest Service, United States Department of Agriculture, Albany, CA.

55. Swiecki, T. J., and Bernhardt, E. 2005. Disease risk factors and disease progress in coast live oak and tanoak affected by Phytophthora ramorum canker (Sudden Oak Death). Pages 383-411 in: Proc. Sudden Oak Death Sci. Symp. II. P. J. Shea and M. Haverty, eds. Pacific Southwest Research Station, Forest Service, United States Department of Agriculture, Albany, CA.

56. Systat Software Inc. 2003. Systat Version 11.0. Systat Software Inc., Chicago.

57. Thompson, J. N. 1999. The evolution of species interactions. Science 284:2116-2118.

58. University of California, Geospatial Innovation Facility. 2010. Oakmapper: Monitoring Sudden Oak Death. http://kellylab.berkeley.edu/oakmapper

59. USDA Forest Service RSL. 2003. CALVEG Vegetation Mapping Program. 1920 20th Street, Sacramento, CA. http://www.fs.fed.us/ r5/fsl/projects/mapping/

60. Welch, B. L. 1951. On the comparison of several mean values: An alternative approach. Biometrika 38:330-336.

61. Werres, S., Marwitz, R., Man in't Veld, W. A., De Cock, A. W. A. M., Bonants, P. J. M., De Weerdt, M., Themann, K., Ilieva, E., and Baayen, R. P. 2001. Phytophthora ramorum sp. nov., a new pathogen on Rhododendron and Viburnum. Mycol. Res. 105:1155-1165.

62. Wickland, A. C., Jensen, C. E., and Rizzo, D. M. 2008. Geographic distribution, disease symptoms and pathogenicity of Phytophthora nemorosa and Phytophthora pseudosyringae in California, USA. For. Pathol. 38:288-298.

63. Wright, I., Reich, P., Westoby, M., Ackerly, D., Baruch, Z., Bongers, F., Cavender-Bares, J., Chapin, T., Cornelissen, J., Diemer, M., Flexas, J., Garnier, E., Groom, P., Gulias, J., Hikosaka, K., Lamont, B., Lee, T., Lee, W., Lusk, C., Midgley, J., Navas, M., Niinemets, U., Oleksyn, J., Osada, N., Poorter, H., Poot, P., Prior, L., Pyankov, V., Roumet, C., Thomas, S., Tjoelker, M., Veneklaas, E., and Villar, R. 2004. The worldwide leaf economics spectrum. Nature 428:821-827. 